\title{
Assessment of functional gametes in chickens after transfer of primordial germ cells
}

\author{
J. N. Petitte*, M. E. Clark and R. J. Etches \\ Department of Animal and Poultry Science, University of Guelph, Guelph, Ontario, \\ Canada, NIG $2 W I$
}

\begin{abstract}
Summary. The ability of primordial germ cells (PGCs) transferred from donor to recipient embryos to form functional gametes was assessed using feather colour as a phenotypic marker. Donor primordial germ cells were obtained in blood samples taken from Dwarf White Leghorn embryos, homozygous for the dominant allele at the locus for 'dominant white' plumage $(I)$, which had been incubated for $52 \mathrm{~h}$. Blood samples containing PGCs were transferred by intravascular injection to Barred Plymouth Rock embryos (ii) incubated for 53, 72 and $96 \mathrm{~h}$. Of the embryos which hatched, 28 were male and 31 were female. All chicks were raised to sexual maturity and test mated with Barred Plymouth Rock fowl. All of the 3117 offspring exhibited the typical Barred Plymouth Rock phenotype; no Barred Plymouth Rock $\times$ Dwarf White Leghorn chicks were obtained. The results of this study suggest that the frequency of transmission of the donor line genotype after PGC transfer must be improved for this technique to be useful for the routine development of transgenic poultry.
\end{abstract}

Keywords: chicken; embryo; primordial germ cell; transgenic

\section{Introduction}

The successful application of recombinant DNA technology in the production of transgenic animals requires the development of efficient methods of introducing exogenous genes into the recipient animal. Transgenic mice are commonly produced by microinjection of DNA into the pronucleus of the newly fertilized egg (Palmiter et al., 1982), by infection with retroviral vectors (Jaenisch, 1976), or through the transfection of embryonic stem cells and the formation of germline chimaeras (Gossler et al., 1986; Robertson et al., 1986). In chickens, foreign DNA has been inserted into the germ-line through the infection of unincubated embryos with replicationcompetent or replication-defective retroviruses (Salter et al., 1987; Bosselman et al., 1989). Another approach towards the development of transgenic poultry involves the use of primordial germ cells (PGCs), which are the progenitors of egg and sperm cells.

In birds, PGCs arise from the epiblast and migrate to the hypoblast within the first few hours of incubation (Eyal-Giladi et al., 1981; Sutasurya et al., 1983; Urven et al., 1988). During gastrulation, the PGCs migrate anteriorly via the hypoblast and reside in the extraembryonic area referred to as the germinal crescent (Swift, 1914; Ginsburg \& Eyal-Giladi, 1986). Concomitant with the formation of the extraembryonic vasculature, PGCs can be found in blood samples up to about $65 \mathrm{~h}$ of incubation. Thereafter, the number of cells in the vasculature declines as the cells settle into the gonadal ridge (Singh \& Meyer, 1967; Swartz \& Domm, 1972). This developmental history of PGCs suggests that access to and genetic modification of these cells during vascular migration would facilitate the insertion of novel genes into the germ-line.

*Present address: Department of Poultry Science, Box 7608, North Carolina State University, Raleigh, NC 276957608, USA. 
Reynaud (1969) was the first to demonstrate the extragonadal origin of PGCs by injecting germinal crescent cells into the extraembryonic vasculature of sterilized recipient embryos. Recently, Simkiss et al. (1989) transferred blood containing PGCs from endogenous retroviralpositive donors into retroviral-negative recipients and reported the presence of the viral DNA in embryonic gonadal tissue. Nevertheless, the ability of these introduced PGCs to produce functional gametes has not been examined. The purpose of the present study was to transfer PGCs between embryos and to test for the presence of the donor genotype in the germ-line.

\section{Materials and Methods}

Primordial germ cells were obtained from an inbred line of OAC Dwarf White Leghorns, which is homozygous dominant for $I$ at the locus for 'dominant white' plumage. The recipients were from the OAC Barred Plymouth Rock line, which is homozygous for the recessive allele $(i)$ of 'dominant white'.

Donor embryos were incubated for about 50-55 h to reach stage 13-15 (Hamburger \& Hamilton, 195l). These embryos were removed by placing a filter paper ring over the perimeter of the vitelline circulation, cutting the vitelline membrane along the outer edge of the ring and lifting the ring and embryo off the yolk. Isolated embryos were placed ventral side up in Medium 199 with Hepes buffer and gently washed free of yolk. Under a dissection microscope with ventral illumination, a blood sample was obtained at the junction of the dorsal aorta and vitelline arteries using a finely drawn micropipette. Approximately one-half of the blood sample was smeared on a microscope slide and air dried. To estimate the number of PGCs in the blood sample, the blood smears were stained with periodic acid-Schiff (PAS) (Fujimoto et al., 1976) and the numbers of PGCs were recorded. The remaining material was used for transfer into recipient embryos.

Recipient embryos were incubated for 53,72 , or $96 \mathrm{~h}$. A window was made at the blunt end of the egg over the air cell and a blood vessel was exposed by removing a small piece of the inner shell membrane. The blood sample was injected into the exposed blood vessel of the embryos incubated for 72 or $96 \mathrm{~h}$. For transfer to embryos incubated for $53 \mathrm{~h}$, the blood sample was deposited next to a blood vessel, often within the extraembryonic coelom. After injection, the window was sealed with a glass coverslip and wax.

All hatched chicks were raised to sexual maturity and were mated with Barred Plymouth Rock fowl. All offspring from the test crosses were examined for the heterozygous 'dominant white' phenotype (genotype $I$ ). which would indicate the presence of the Dwarf White Leghorn genotype in the population of gametes. Control crosses consisted of reciprocal matings between Barred Plymouth Rock and Dwarf White Leghorn fowl.

\section{Results}

The hatchability of the recipient embryos which were injected at 53,72 and $96 \mathrm{~h}$ was $68 \cdot 6,76 \cdot 3$ and $71 \cdot 4 \%$, respectively. Of all the chicks hatched, $52 \cdot 5 \%$ were female and $47 \cdot 5 \%$ were male.

Of the 59 recipient embryos which survived to hatch, 28 were injected with blood which contained at least one PGC in the uninjected sample, 18 were injected with blood that did not have any PGCs in the remaining sample, and the blood used for 13 embryos was not evaluated for the presence of PGCs (Table 1). If the extreme value of 48 is excluded, the average number of PGCs in the 27 uninjected blood samples containing one or more PGCs was 3.5. Assuming that the injected and uninjected aliquots of blood contained equal numbers of cells, each recipient received 3-4 PGCs.

Of the 3117 chicks obtained from the test crosses, all exhibited the Barred Plymouth Rock phenotype (Table 1). If the PGCs which were transferred with the Dwarf White Leghorn embryonic blood sample were capable of producing functional gametes, a portion of the offspring would be expected to exhibit the heterozygous 'dominant white' phenotype observed in the control crosses between the Barred Plymouth Rock and Dwarf White Leghorn fowl.

\section{Discussion}

The inability to detect the Dwarf White Leghorn genotype in the test crosses could be explained by a failure of the PGCs to colonize the gonad, a low frequency of gametogenesis by the PGCs, or an 
Table 1. Number of chicks that completed development and reached sexual maturity after injections of blood from donor Dwarf White Leghorn embryos incubated for $53 \mathrm{~h}$ into Barred Plymouth Rock recipients incubated for the times shown and the number of primordial germ cells (PGCs) contained in an equal volume of donor blood

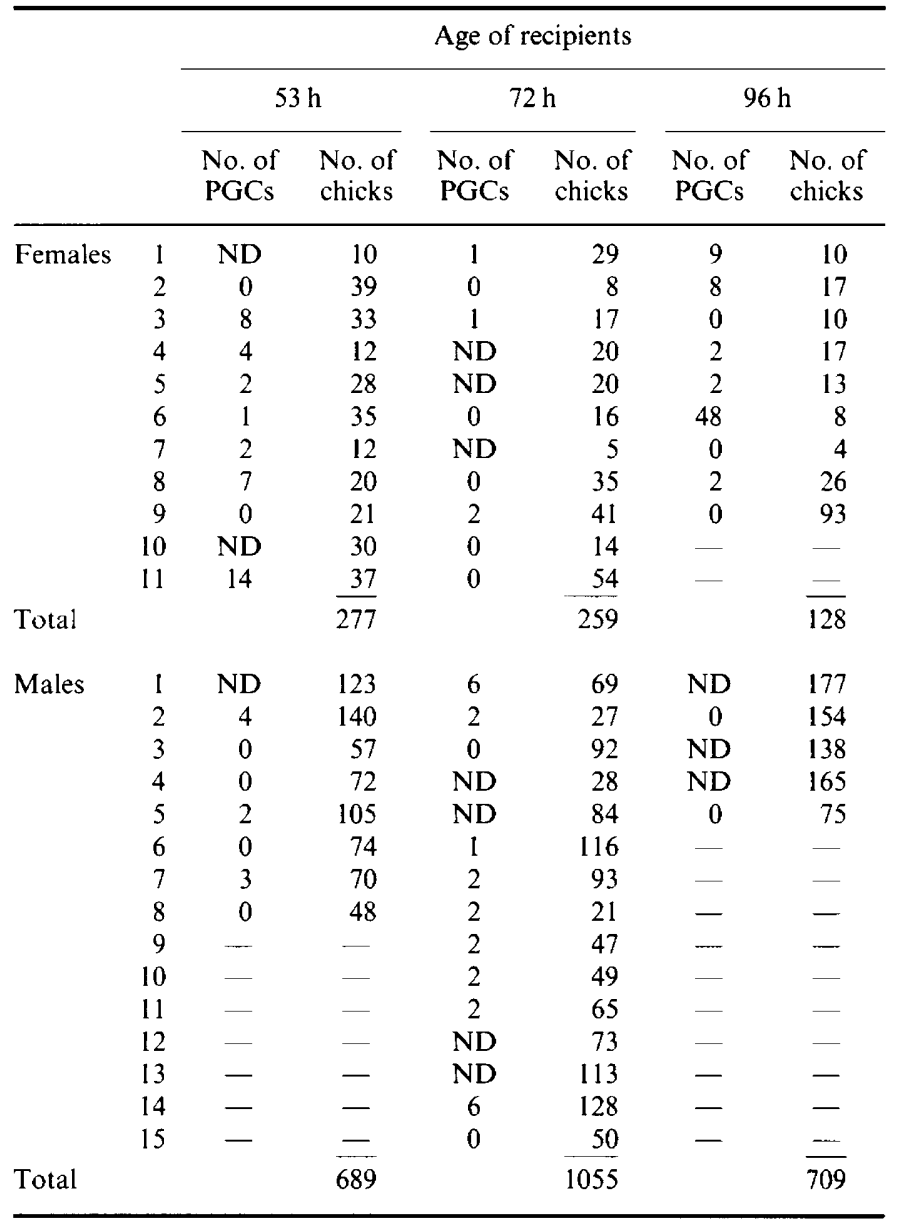

ND, not determined.

All offspring were phenotypically Barred Plymouth Rocks.

inability of the gametes derived from the exogenous PGCs to undergo normal spermatogenesis or oogenesis, making such gametes infertile. Several studies indicate that it is unlikely that the introduced PGCs failed to colonize the gonad. It has been well established in vivo and in vitro that the migration of primordial germ cells from the embryonic circulation to the gonadal ridge is the consequence of a chemotaxic phenomenon which involves active migration of the PGCs through nonvascular tissues (Dubois, 1968; Rogulska, 1969; Fujimoto et al., 1976; Kuwana \& Fujimoto, 1984; Kuwana et al., 1986). Furthermore, Reynaud (1976) was able to transfer a mixture of cells from the germinal crescent, which contained PGCs, by intravascular injection of 3-5-day sterilized embryos and observed colonization of the exogenous PGCs in the host gonad. Using a marker chromosome, Shuman (1981) transferred isolated germinal crescent PGCs to embryos of a similar stage and likewise observed the donor cell within the host gonad. Simkiss et al. (1989), using an 
endogenous retroviral marker, demonstrated the presence of viral DNA in embryonic gonadal tissue after intravascular injection. Wentworth et al. (1989) reported the successful transfer of PGCs to the vasculature in quails, resulting in the recovery of a phenotypic marker in a subsequent test cross; however, the frequency of transmission was not reported.

The number of PGCs which colonized the gonad may have been too low to contribute significantly to the gamete pool. At the time of transfer, there are about 200 PGCs at $53 \mathrm{~h}$ of incubation and 1000 PGCs at 72 and $96 \mathrm{~h}$ of incubation (Swartz \& Domm, 1972). Assuming the incorporation of an average of 3.5 PGCs into the gonadal ridge for the 27 embryos which were injected with blood containing PGCs (see Results) and an equal potential for gametogenesis, the proportion of gametes originating from the donor genotype would be $1.75 \%$ for the embryos injected at $53 \mathrm{~h}$, and $0.37 \%$ for the embryos injected at 72 and $96 \mathrm{~h}$ of incubation. If these proportions are multiplied by the number of offspring produced by each of the 27 embryos injected with blood containing PGCs, 11 of these would be expected to exhibit the 'dominant white' phenotype.

The number of PGCs injected into the embryo could be increased by separation or enrichment techniques including differential plating (Shuman, 1981), density centrifugation, elutriation and fluorescence-activated cell sorting (Wentworth et al., 1989). Although these techniques would increase the proportion of donor PGCs in the recipient, they may have detrimental effects on PGC viability. From a technical perspective, PGCs comprise only a small fraction of the total number of blood cells and, therefore, blood samples from several embryos would be required to obtain each injection of PGCs. Since the sex of the donor is unknown at the time of collection, the concentration of PGCs could lead to mixed-sex chimaerism and consequently to abnormal processing in the gonad.

It is unclear how donor PGCs would devleop in transfers of ZZ PGCs into a ZW gonad or vice versa. In Xenopus, transplantation experiments reveal that the chromosomal sex of the PGCs is unrelated to their subsequent development as ova or spermatozoa and that functional $\mathrm{ZZ}$ and $\mathrm{ZW}$ PGCs will produce both Z- and W-bearing eggs and spermatozoa in either an ovary or a testis (Blackler, 1965). In contrast to Xenopus, Hajji et al. (1988), using chick-chick or quail-chick chimaeras, demonstrated that the phenotypic sex of the embryonic gonad always corresponds to the genetic sex of the stroma. However, Haffen (1975) noted that male germ cells will degenerate in an embryonic chick ovary. In mice, the situation is unclear since the techniques used to produce mixed-sex chimaeras always lead to both stromal and germ-cell chimaerism. In general, few female murine mixed-sex chimaeras have been found. Most often, mixed-sex chimaeras develop as phenotypic males in which the female germ-cell population does not produce functional spermatozoa (Mintz, 1968; Mystkowksa \& Tarkowski, 1968; McLaren, 1975). Furthermore, chimaeras produced from the injection of male embryonic stem cells into female blastocysts develop into phenotypic males in which the progeny are derived exclusively from the donor cells (Evans et al., 1985). Interestingly, Mintz (1968) observed what appeared to be time-dependent, germ-cell selection in a single-sex male chimaera; the donor genotype was transmitted through the germ-line only transiently at the onset of reproduction. In birds, Wentworth et al. (1989) reported a similar phenomenon while test mating quail after intravascular PGC transfer. Recently, Petitte et al. (1990) developed somatic and germ-line chimaeras by blastodermal cell transfer and reported a 1 in 400 frequency of germ-line transmission.

Taken together, these observations and the results of the present study suggest that the low frequency of germ-line transmission after transfer of vascular PGCs may be due to insufficient numbers of and/or the abnormal development of donor primordial germ-cells. In any case, the frequency of transmission of the donor genotype after PGC transfer must be improved before this technique can be used for the routine development of transgenic poultry.

This work was supported by the Ontario Egg Producers Marketing Board and the Ontario Ministry of Agriculture and Food. The technical assistance of the staff of the Arkell Poultry Research Station is gratefully acknowledged. 


\section{References}

Blackler, A.W. (1965) Germ cell transfer and sex ratio in Xenopus laevis. J. Embryol. exp. Morph. 13, 51-61.

Bosselman, R.A., Hsu, R., Boggs, T., Hu, S., Bruszewski, J., Ou, S., Kozar, L., Martin, F., Green, C., Jacobsen, F., Nicholson, M., Schulz, J.A., Semon, K.M., Richell, W. \& Stewart, R.G. (1989) Germline transmission of exogenous genes in the chicken. Science, N.Y. 243 , $533-535$.

Dubois, R. (1968) La colonisation des ébauches gonadiques par les cellules germinales de l'embryon de poulet, en culture in vitro. J. Embryol exp. Morph. 20, 189-213.

Eyal-Giladi, H., Ginsburg, M. \& Farbarov, M. (1981) Avian primordial cells are of epiblastic origin. $J$. Embryol. exp. Morph. 65, 139-147.

Evans, M., Bradley, A. \& Robertson, E. (1985) EK cell contribution to chimeric mice: from tissue culture to sperm. In Banbury Report 20: Manipulation of the Early Mammalian Embryo. pp. 93-102. Cold Spring Harbor Laboratory, NY.

Fujimoto, T., Ninomiya, T. \& Ukeshima, A. (1976) Observations of the primordial germ cells in blood samples from the chick embryo. Dev. Biol. 49, 278-282.

Ginsburg, M. \& Eyal-Giladi, H. (1986) Temporal and spatial aspects of the gradual migration of primordial germ cells from the epiblast into the germinal crescent in the avian embryo. J. Embryol. exp. Morph. 95, 5371 .

Gossler, A., Doetschman, T., Korn, R., Serfling, E. \& Kemler, R. (1986) Transgenesis by means of blastocystderived embryonic stem cell lines. Proc. natl Acad. Sci. USA 83, 9065-9069.

Haffen, K. (1975) Sex differentiation of avian gonads in vitro. Amt. Zool. 15, 257-272.

Haji, K., Martin, C., Perramon, A. \& Dieterlen-Lievre, F. (1988) Sexual phenotype of avian chimeric gonads with germinal and stromal cells of the opposite genetic sexes. Biol. Struct. and Morphog. 1, 107-116.

Hamburger, V. \& Hamilton, H.L. (1951) A series of normal stages in the development of the chick. $J$. Morph. 88, 49-92.

Jaenisch, R. (1976) Germ line integration and Mendelian transmission of the exogenous moloney leukemia virus. Proc. natl Acad. Sci. USA 73, $1260-1264$.

Kuwana, T. \& Fujimoto, T. (1984) Locomotion and scanning electron microscopic observations of primordial germ cells from embryonic chick blood in vitro. Anat. Rec. 209, 337-343.

Kuwana, T., Maeda-Suga, H. \& Fujimoto, T. (1986) Attraction of chick primordial germ cells by gonadal anlage in vitro. Anat. Rec. 215, 403-406.

McLaren, A. (1975) Sex chimerism and germ cell distribution in a series of chimeric mice. J. Embryol. exp. Morph. 33, 205-216.

Mintz, B. (1968) Hermaphroditism, sex chromosomal mosaicism and germ cell selection in allophenic mice. J. Anim. Sci. (Suppl. I), 27, 51-60.

Mystkowska, E.T. \& Tarkowski, A.K. (1968) Observations on CBA-p/CBA-T6T6 mouse chimeras. $J$. Embryol. exp. Morph. 20, 33-52.
Palmiter, R.D., Brinster, R.L., Hammer, R.E., Trumbauer, M.E., Rosenfeld, M.G., Birnberg, N.C. \& Evans, R.M. (1982) Dramatic growth of mice that develop from eggs microinjected with metallothionein-growth hormone fusion genes. Nature, Lond. 300, 611-615.

Petitte, J.N., Clark, M.E., Liu, G., Verrinder Gibbins, A. \& Etches, R.J. (1990) Production of somatic and germline chimeras in the chicken by transfer of early blastodermal cells. Development 108, 185-189.

Reynaud, G. (1969) Transfert de cellules germinales primordiales de dindon à l'embryon de poulet par injecton intravasculaire. J. Embryol. exp. Morph. 21, $485-507$.

Reynaud, G. (1976) Capacités reproductrices et descendance de poulets ayant subi un transfert de cellules germinales primordiales durant la vie embryonnaire. Wilhelm Roux's Arch. 179, 85-110.

Robertson, E., Bradley, A., Kuehn, M. \& Evans, M. (1986) Germ-line transmission of genes introduced into cultured pluripotential cells by retroviral vector. Nature, Lond. 323, 445-448.

Rogulska, T. (1969) Migration of the chick primordial germ cells from the intracoelomically transplanted germinal crescent into the genital ridge. Experientia 25, $631-632$.

Salter, D. W., Smith, E.J., Hughes, S.H., Wright, S.E. \& Crittenden, L.B. (1987) Transgenic chickens: insertion of retroviral genes into the chicken germ line. Virology 157, 236-240.

Shuman, R.M. (1981) Primordial germ cell transfer in the chicken, Gallus domesticus. M.S. thesis, University of Minnesota, St. Paul.

Simkiss, K., Rowlett, K., Bumstead, N. \& Freeman, B.M. (1989) Transfer of primordial germ cell DNA between embryos. Protoplasma 151, 164-166.

Singh, R.P. \& Meyer, D.B. (1967) Primordial germ cells in blood smears from chick embryos. Science, N.Y. 156, 1503-1504.

Sutasurya, L.A., Yasugi, S. \& Mizuno, T. (1983) Appearance of primordial germ cells in young chick blastoderms cultured in vitro. Dev. Growth Differ. 25, $517-521$.

Swartz, W.J. \& Domm, L.V. (1972) A study on the division of primordial germ cells in the early chick embryo. Am. J. Anat. 135, 51-70.

Swift, C.H. (1914) Origin and early history of the primordial germ-cells in the chick. Am. J. Anat. 15, 483-516.

Urven, L.E., Erickson, C.A., Abbot, U.K. \& McCarrey, J.R. (1988) Analysis of germ line development in the chick embryo using an antimouse EC cell antibody. Development 103, 299-304.

Wentworth, B.C., Tsai, H., Hallett, J.H., Gonzales, D.S. \& Rajcic-Spasojevic, G. (1989) Manipulation of avian primordial germ cells and gonadal differentiation. Poultry Science 68, 999-1010.

Received 21 September 1990 